\title{
Shared Management of Water Resources among Sovereign States in Latin America: The Case of the River Plate Basin
}

\author{
Olga Kelman Brocki Calhman1, Monica de Aquino Galeano Massera da Hora ${ }^{2 *}$ \\ ${ }^{1}$ Environmental Water Resources Laboratory, Department of Agricultural and Environmental Engineering, \\ Fluminense Federal University, Niteroi, Rio de Janeiro, Brazil \\ ${ }^{2}$ Master's Program in Civil Defense and Security, Fluminense Federal University, Niteroi, Rio de Janeiro, Brazil \\ Email: *dahora@vm.uff.br
}

Received 6 May 2016; accepted 27 June 2016; published 30 June 2016

Copyright (C) 2016 by authors and Scientific Research Publishing Inc.

This work is licensed under the Creative Commons Attribution International License (CC BY). http://creativecommons.org/licenses/by/4.0/

(c) (i) Open Access

\section{Abstract}

The present article sought to address the issue of shared management of water resources among sovereign states in Latin America, focusing on the hydrographic basin of the River Plate. The methodology of the Transboundary Waters Assessment Programme for river basins proposed by the United Nations was used to evaluate risks within current and future scenarios. The results obtained allow the inference that the River Plate basin is in a moderate-risk category. However, high and very high risk values were observed for the pollution, dams and economic reliance indicators, which in the future horizon could promote conflicts regarding water resource use. In conclusion, states should establish their priorities and clear rules for monitoring, use and surveillance of water. This process should be done in an integrated manner, with due regard for international arrangements, and should be compatible with the policies and management instruments of the countries involved.

\section{Keywords}

Transboundary Rivers, Water Politics, Water Use Conflicts, Risk

\section{Introduction}

It is widely recognized that water resource issues are directly and indirectly related to social, economic and environmental factors and, thus, play an important role in development [1].

${ }^{*}$ Corresponding author.

How to cite this paper: Calhman, O.K.B. and Hora, M.A.G.M. (2016) Shared Management of Water Resources among Sovereign States in Latin America: The Case of the River Plate Basin. Journal of Environmental Protection, 7, 1089-1095. 
The small portion of freshwater that is suitable for human consumption demonstrates the need for sustainable use of reserves. Over the past five decades, these reserves have undergone drastic quantitative and qualitative reductions. These reductions have especially been due to population growth, major expansion of industrial capacity and direct discharge of untreated domestic, industrial and agricultural effluents.

The risk of future global climate changes, i.e. additional warming of the planet, may alter the hydrological cycle and, thus, the water-resource regime and water availability in different hydrographic basins [2].

The water-resource potential and climatic characteristics of Brazil provide it with a significant advantage, in global comparisons. Brazil has the largest availability of renewable freshwater on the planet, and is a member of a privileged group of seven countries (Brazil, Russia, Canada, China, Indonesia, United States and Bangladesh), which together hold $50 \%$ of this availability. The remaining $50 \%$ is shared by another 154 countries, among which 92 countries, with the lowest proportions of renewable freshwater availability, together hold only $5 \%$ of this portion. These numbers demonstrate how water is badly distributed.

Control and management of natural resources also involve issues relating to international law, such as sovereignty and territory. Thus, management of water resources at and across national borders deserves particular attention, especially in Brazil, which shares $88 \%$ of its water potential [3].

The objective of the present study was to provide an overview on the issue of water resource management in river basins at and across national borders by applying the methodology proposed by the river basins component of the Transboundary Waters Assessment Programme (TWAP). The River Plate basin was used here as a case study.

\section{Challenges for Management of Shared Waters}

The ministerial declaration established at the second World Water Forum, in The Hague, in 2000, indicated that the following items should be of main concern in this new century: meet basic needs; guarantee food supply; protect ecosystems; share water resources; administer risks; value water; and administrate water sensibly. At this forum, the ministerial declaration excluded the term international waters, which had been a point of concern for countries with abundant water resources, such as Brazil. The expression was replaced by boundary and transboundary rivers.

The notion of boundary and transboundary waters extends hydrological interdependence beyond national borders, thereby establishing a link among users in different countries within a single system. One of the great human development challenges that the international community faces is to manage this interdependence [4]. As the relationship between water availability and water demand becomes smaller, boundary/transboundary competition for sharing water resources increases [5].

Water is widely shared between nations, regions, ethnic groups and communities. The consumption of water upstream determines the options downstream regarding management, thus creating scenarios for either dispute or cooperation.

The number of transboundary river basins has tended to increase with political changes ("internationalization" of basins) or through better mapping technologies. According to [6], 286 shared basins were delineated.

One frequent situation in water resource management is comparison between availability and demand for water in a hydrographic basin. Demand is calculated according to the current and future use of the water. Availability is the supply of water provided by the basin, which depends on the natural characteristics of the basin and on the climate in the region, and can be altered through creation of reservoirs or through transposing water from neighbouring basins [7].

Geopolitical conflicts regarding management of transboundary water basins have always existed. The Portuguese language reflects these ancient roots: "rivalidade" (rivalry) comes from the Latin word rivalis, meaning "he who uses the same river as the other". Countries or provinces that are neighbours across a river ("riparian") are frequently rivals regarding shared water. The term "conflict", from the Latin conflictu, has the meanings of "discussion", "disorder", "opposition" or "critical moment". According to [8], a conflict is a collision of interests. According to [9], conflict is competition for a scarce resource. [10], in turn, defined conflict as a natural divergence that arises from coexistence of people or groups that differ in attitudes, beliefs, values or needs.

Conflicts arising from direct use of water can originate from many factors, such as: variability of availability of water and uncertainties regarding its occurrence; disparity in levels of development and use of water resources among neighbouring nation-states; need for food security and self-sufficiency; growing scarcity of water 
resources as a consequence of increased demand and use; decreased water quality resulting from human activities; interdependency among several water users; and organization of nations that does not coincide with the geography of the water.

[11] Observed that the most significant conflicts involving transboundary waters occur due to disputes regarding their use, pollution issues and equal access to resources in situations of either absolute or relative scarcity. Regarding equal access, [12] noted that most issues concerning water allocation are defined either through market solutions or through cooperative joint development of projects [13].

In water markets in which the value of water is established through the laws of the free market, users who make use of the asset with greater economic efficiency buy the usage rights of other users who do so with less efficiency. Despite the advantages of these markets, most countries do not adopt this system because of the complexity of creating the necessary conditions for it to function adequately. [14] highlighted the experiences of the western United States and Chile. These examples demonstrate that for these markets to work well, government intervention is still highly important.

In turn, [15] identified that the difficulties in managing boundary and transboundary water resources relate to the nonexistent or incipient nature of institutional arrangements and international deals aimed towards shared management; to deficiencies of knowledge regarding hydrological and climatic phenomena and their influence on water availability; to differences that exist between demand characteristics and current and future water-resource interventions; and to the policies and management instruments for water resources and the institutional and legal frameworks of the various countries that share these water bodies. Moreover, institutional arrangements, composed of bodies from different countries, have not been structured for integrated management of water resources in which hydrographic basins serve as management units. There are also gaps in scientific knowledge, which generate uncertainties regarding evaluations of water availability and forecasting of critical events, such as rainy and dry periods. In addition, the characteristics of the economic activities and socioeconomic development stages of countries with transboundary water bodies give rise to differences in demands and water-resource interventions.

Thus, the directives for assigning priorities of attention are different. ANA also observed that countries have different legal provisions, water-resource policies and degrees of implementation of water management systems, which makes it more difficult for management instruments and practices to become integrated and compatible. Consequently, the institutional framework generally lacks executive and deliberative organizations that are capable of applying water resource management instruments in an integral manner [15]. This situation creates the need for a process of negotiations and building of consensuses.

The issue of shared water resources is in fact one of the most ancient themes of diplomacy, because it relates not only to use of hydric resources, but also to sovereignty of nation-states. The multiplicity of factors involved in this issue shows that if it is addressed from an international perspective, Brazil's vital interests are put into play [16]. Water resource management at the transboundary basin level requires that the basin should be considered to be a single planning and management unit. This implies not only that the water resources shared between nation-states along the course of the river, but also all the components associated with the territory should be taken into consideration. Thus, there is a need to advance towards an economic-social ecosystem-based conception for integrated management of natural resources at basin level, through the understanding that a transboundary hydrographic basin consists of a territory belonging to riverine states that share a common hydrological system [17].

[18] reported that the following instruments should be used for integrated management of water resources: evaluation of water resources (comprehension of resources and needs); plans for integrated water resource management (IHRM) (combination of development options, use of resources and human interaction); demand management (more efficient use of water); social change instruments (promotion of water-oriented civil society); conflict resolution (dispute management and guaranteed shared use of water); regulatory instruments (allocation and limits to water use); economic instruments (value and price used for efficiency and equity); and information management and exchange (improvement of knowledge to enable better water management).

This array of instruments demonstrates that integrated management of transboundary basins establishes challenges of administrative, legal, cultural, institutional and economic nature [19].

The transboundary theme is essential within the Brazilian context, considering that, in addition to the thousands of kilometres of terrestrial borders with 10 other countries, nearly $60 \%$ of the national territory is within hydrographic basins that extend into neighbouring countries. According to [20], Brazil is part of two major hy- 
drographic systems: the Amazon basin and the River Plate basin, sharing its waters with seven and four countries, respectively. In the River Plate basin, Brazil is the upstream sovereign state, which allows this country to sometimes hold opposing positions to those held for the Amazon basin in international agreements regarding freshwater, as illustrated in Figure 1. These different geographic positions cause Brazil to defend the hypothesis that rules for environmental management and planning of these areas cannot be defined within multilateral international agreements. This could perhaps explain why negotiations that involve transboundary rivers have developed within the field of bilateral treaties [21].

In a global survey of boundary and transboundary interactions, a total of 1,831 interactions between nationstates were observed, of which 507 were identified as conflictive, 1,228 cooperative and 96 either neutral or insignificant [22]. However, as observed by [23], cooperation does not always result from proactive action: most of the time it is reactive, especially if there is conflict regarding the amount of water used or sovereignty interests. It can also be reactive when it relates to hydraulic construction projects, which almost exclusively involves the course of the river and not the hydrographic basin. The issue of hydroelectric exploitation is of particular importance given that in relation to either granting the use of water resources to an institution or company or authorizing potential use of hydraulic energy, ANA restricts the hydroelectric use to the monthly mean flow rates corresponding to the difference between the natural flow at the location of the enterprise and the consumption upstream from it [24]. This means that all water use upstream from the enterprise will be restricted to the values granted by ANA. In the case of transboundary rivers (such as the River Madeira with the hydroelectric projects of Jirau and Santo Antonio), the possible conflicts that come from this restriction may assume international proportions [25].

\section{Methodology}

The present study followed the methodology proposed by the Transboundary Waters Assessment Programme (TWAP), which was created by the Global Environment Facility (GEF) as the first evaluation of transboundary water resources in the world [26].

The programme enables verification of the status of each transboundary basin by means of indicators, through simulating scenarios for the baseline and for the years 2030 and 2050. Five groups of systems are taken into

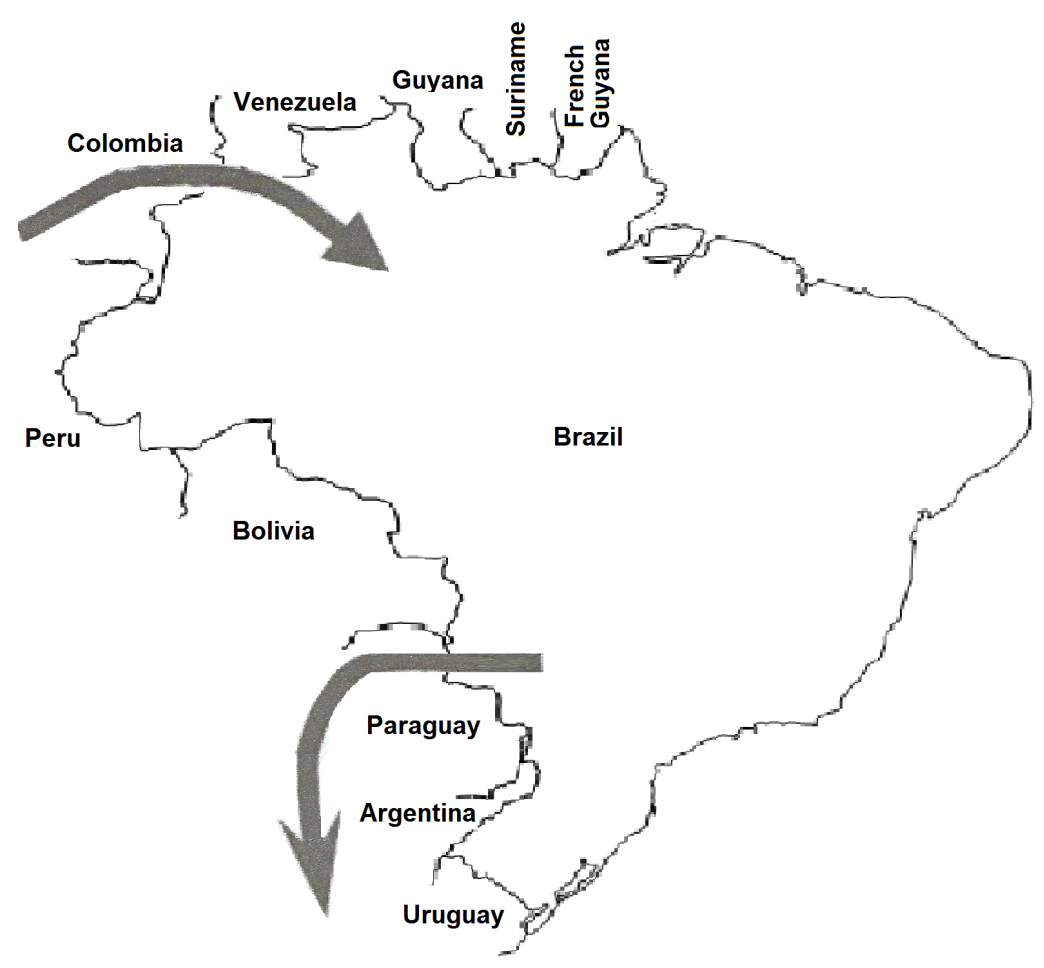

Figure 1. Water flow in the Amazon and River Plate basins (Adapted from [20]). 
consideration: 1) groundwater; 2) lake basins; 3) river basins; 4) large marine ecosystems; and 5) open ocean. The present study applied the Transboundary Waters Assessment Programme for river basins (TWAP-RB), which is available through the website http://twap-rivers.org/indicators/.

TWAP-RB uses methodology that involves a certain number of indicators, by means of comparative analysis between basins. Five thematic groups were identified as relevant for populations and for ecosystems: amount of water, water quality, ecosystems, governance and socioeconomics. The evaluation establishes relative levels of risk that range from 1 to 5 , as described in Table 1 .

\section{Results Achieved}

The River Plate basin was simulated using the TWAP-RB portal. This basin combines territories in Argentina, Brazil, Bolivia, Paraguay and Uruguay, and was considered in terms of sub-basin units (basin country unit, $\mathrm{BCU})$. The evaluations of risk scenarios that were obtained for the baseline are described in Table 2.

The TWAP-RB does not necessarily simulate the same indicators for the projected scenarios of the years 2030 and 2050 as were used for the baseline. Thus, we chose to present the results relating to the "amount of water" and "governance" thematic groups for these projected scenarios separately in Table 3.

Table 1. Risk categories.

\begin{tabular}{cc} 
Risk Level & Category \\
\hline 1 & Very Low \\
2 & Low \\
3 & Moderate \\
4 & High \\
5 & Very High \\
\hline
\end{tabular}

Table 2. Indicators according to territory and for the total area of the River Plate basin. Scenario: baseline.

\begin{tabular}{|c|c|c|c|c|c|c|}
\hline \multirow{2}{*}{$\begin{array}{c}\text { THEMATIC GROUP } \\
\text { BCU }\end{array}$} & \multicolumn{2}{|c|}{ Amount of water } & \multirow{2}{*}{$\begin{array}{c}\text { Water quality } \\
\text { B }\end{array}$} & \multirow{2}{*}{$\begin{array}{c}\text { Ecosystems } \\
\text { C }\end{array}$} & \multirow{2}{*}{$\begin{array}{c}\text { Governance } \\
\text { D }\end{array}$} & \multirow{2}{*}{$\begin{array}{c}\text { Socioeconomics } \\
\text { E }\end{array}$} \\
\hline & A1 & $\mathrm{A} 2$ & & & & \\
\hline ARGENTINA & 1 & 2 & 5 & 4 & 3 & 4 \\
\hline BOLIVIA & 1 & 2 & 5 & 3 & 2 & 3 \\
\hline BRAZIL & 1 & 2 & 5 & 4 & 3 & 5 \\
\hline PARAGUAY & 1 & 2 & 5 & 3 & 3 & 5 \\
\hline URUGUAY & 1 & 2 & 5 & 4 & 3 & 3 \\
\hline ENTIRE BASIN & 1 & 2 & 5 & 4 & 3 & 5 \\
\hline
\end{tabular}

Legend: (A1) human water-resource stress; (A2) environmental water-resource stress; (B) wastewater pollution; (C) impacts caused by dams; (D) water-resource policy tension; (E) economic reliance on water resources.

Table 3. Indicators according to territory and for the total area of the River Plate basin. Scenario: 2030 and 2050.

\begin{tabular}{cccccc}
\hline THEMATIC GROUP & \multicolumn{9}{c}{ Amount of water } & Governance \\
\hline BCU & A1 (2030) & A1 (2050) & A2 (2030) & A2 (2050) & $\begin{array}{c}\text { Projected water resource } \\
\text { policy tension }\end{array}$ \\
\hline ARGENTINA & 1 & 2 & 3 & 3 & 3 \\
BOLIVIA & 1 & 1 & 3 & 3 & 2 \\
BRAZIL & 1 & 1 & 2 & 2 & 3 \\
PARAGUAY & 1 & 1 & 2 & 2 & 3 \\
URUGUAY & 1 & 1 & 3 & 3 & 3 \\
\hline
\end{tabular}

Legend: (A1) human water-resource stress; (A2) environmental water-resource stress. 
Based on Table 2 and Table 3, we can infer that the River Plate basin is within a moderate category of risk. However, the baseline scenario presented high and very high risk categories for the pollution, dams and economic reliance indicators, which in the near future could promote conflicts over the use of water resources.

\section{Conclusions}

Boundary and transboundary water resources do not respect political boundaries. However, they are crucial for development and become pressure points in regions where water resources are scarce and distribution is unequal.

There are now many treaties and agreements, as well as studies, in which the objective is to define and improve strategies for improvement of governance. However, even though these treaties and agreements address sectorial issues such as water transportation, hydroelectric use and water use in some portions of rivers, they are not consonant with integrated management of water resources, because sometimes they establish generic criteria and procedures.

Since the theme of boundary and transboundary water resources fits within the scope of sovereignty, it is appropriate that states should establish their priorities and that, in a combined and consensual manner, they should establish clear pacts and rules for monitoring, use and surveillance of water. This process should be carried out in an integrated manner, with due regard for international agreements, which should be compatible with the policies and management instruments of the countries involved.

Therefore, for all these issues to be addressed, bodies and entities that deal with water-related issue in these basins need to combine efforts in order to consolidate boundary and transboundary water management. This should begin with capacitation and qualification of personnel for addressing issues relating to water-resource policies that may arise.

\section{References}

[1] Kallioras, A., Pliakas, F. and Diamantis, I. (2006) The Legislative Framework and Policy for the Water Resources Management of Transboundary Rivers in Europe: The Case of Nestos/Mesta River, between Greece and Bulgaria. Environmental Science \& Policy, 9, 291-301. http://dx.doi.org/10.1016/j.envsci.2005.12.001

[2] Freitas, M.A.V. and Soito, J.L.S. (2008) Energia e recursos hídricos: Vulnerabilidade, impactos e possibilidades de adaptação da energia hidroelétrica no Brasil às mudanças climáticas globais. Revista Parcerias Estratégicas, 27, $177-$ 216.

[3] Silveira, C.A.C., Mejia, L., Ferreira, R.S.A., Guilhon, L.G.F., Silva, O.B. and Freitas, M.A.V. (1999) Água e Energia Elétrica. In: O Estado das Águas no Brasil, Publ. ANEEL-OMM, Brasília, p. 103-115.

[4] Calhman, O.K.B. (2008) Gestão de Recursos Hidricos em Bacias de Rios Fronteiriços e Transfronteiriços-Rio Quaraí/Bacia do Prata. Tese de Doutorado, COPPE/UFRJ, Rio de Janeiro, RJ, Brasil.

[5] UNDP (2006) Beyond Scarcity: Power, Poverty and the Global Water Crisis. United Nations Development Programme (UNDP). http://dx.doi.org/10.18356/3f59dfee-en

http://www.undp.org/content/dam/undp/library/corporate/HDR/2006\%20Global\%20HDR/HDR-2006-Beyond\%20scar city-Power-poverty-and-the-global-water-crisis.pdf

[6] Lehner, B. and Grill, G. (2013) Global River Hydrography and Network Routing: Baseline Data and New Approaches to Study the World's Large River Systems. Hydrological Processes, 27, 1099-1085. http://dx.doi.org/10.1002/hyp.9740

[7] Collischonn, B., Paiva, R.C.D., Collischonn, W., Meirelles, F.S.C., Schettini, E.B.C. and Fan, F.M. (2011) Modelagem Hidrológica de uma Bacia com Uso Intensivo de Água: Caso do rio Quaraí-RS. Revista Brasileira de Recursos Hídricos, 16, 119-133.

[8] Basar, T. and Olsder, G.J. (1999) Dynamic Noncooperative Game Theory. 2nd Edition, SIAM Classics. http://dx.doi.org/10.1137/1.9781611971132

[9] Homer-Dixon, T.F. (1994) Environmental Scarcities and Violent Conflict: Evidence from Cases. International Security, 19, 5-40. http://dx.doi.org/10.2307/2539147

[10] Hoban, J.T. (2001) Managing Conflict. A Guide for Watershed Partnerships. http://www2.ctic.purdue.edu/KYW/brochures/manageconflict.html

[11] Haftendorn, H. (1999) Water and International Conflict. International Studies Association, 40th Annual Convention, Washington, USA, 16-20.

[12] Kilgour, M.D. and Dinar, A. (2001) Flexible Water Sharing within an International River Basin. Environmental Re- 
sources Economics, 1, 43-60. http://dx.doi.org/10.1023/A:1011100130736

[13] Rogers, P. (1993) The Value of Cooperation in Resolving International River Basin Disputes. Natural Resources Forum, 17, 117-131. http://dx.doi.org/10.1111/j.1477-8947.1993.tb00167.x

[14] Moreira, R.M. (2001) Alocação de Recursos Hídricos em Regiões Semi-áridas. Dissertação de Mestrado, COPPE/ UFRJ, Rio de Janeiro, RJ, Brasil.

[15] Agência Nacional de Águas (2011) Outorga de direito de uso de recursos hídricos—Cadernos de Capacitação em Recursos Hídricos. Agência Nacional de Águas (ANA), 6, 50 p.

[16] Vargas, E.V. (2000) Água e Relações Internacionais. Revista Brasileira de Política Internacional, 43, 178-182. http://dx.doi.org/10.1590/S0034-73292000000100010

[17] Francke, S. (2005). Cuencas hidrográficas transfronterizas y derecho ambiental internacional con énfasis en América del Sur. In: Gallardo, E. and Schmithüsen, F., Eds., La Contribuición del Derecho Forestal? Ambiental al Desarollo Sstentable en América Latina. IUFRO World Series, Vol. 16, International Union of Forest Research Organizations, Vienna, 162-173. http://dx.doi.org/10.3929/ethz-a-005223009

[18] Carriger, S. (2005) Catalisando a Mudança: Um Manual para Desenvolver a Gestão Integrada de Recursos Hídricos (GIRH) e Estratégias de Uso Eficiente da Água. Global Water Partnership.

[19] Pahl-Wostl, C., Bouwen, R., Craps, M., Maurel, P., Mostert, E., Ridder, D. and Thallieu, T. (2004) The Importance of Processes of Social Learning for Transboundary Water Management-Perspectives from the Harmoni COP Project. Institute of Environmental Systems Research, University of Osnabrück, Germany.

[20] Agência Nacional de Águas (2009) Manual de Estudos de Disponibilidade Hídrica para Aproveitamentos Hidrelétricos - Manual do Usuário. Agência Nacional de Águas (ANA), Brasília, 45 p.

[21] Alemar, A. (2006) Geopolítica das Águas. O Direito Internacional Fluvial. Tese de Doutorado. Programa de PósGraduação em Geografia. Instituto de Geografia, Uberlândia, Minas Gerais, MG, Brasil.

[22] Wolf, A.T., Yoffe, S.B. and Giordano, M. (2003) International Waters: Indicators for Identifying Basins at Risk. Department of Geosciences, Oregon State University, Corvallis.

[23] Barbosa, M.C.B.P. (2013) A Gestão das Águas Transfronteiriças e a Hidropolítica. Revista Águas do Brasil, Edição 6.

[24] Agência Nacional de Águas (2013) Conjuntura dos recursos hídricos no Brasil: 2013. Agência Nacional de Águas (ANA), Brasília, $432 \mathrm{p}$.

[25] Hora, M.A.G.M. and Legey, L.F.L. (2015) Water Resource Conflict in the Amazon Region: Hydropower Generation and Multiple-Use Water Systems in the Tocantins and Araguaia River Basins. Journal of Water Resource and Hydraulic Engineering, 4, 229-235. http://dx.doi.org/10.5963/JWRHE0403002

[26] UNEP (2016) Transboundary River Basins: Status and Trends. United Nations Environment Programme (UNEP), Nairobi. http://twap-rivers.org/

\section{Submit or recommend next manuscript to SCIRP and we will provide best service for you:}

Accepting pre-submission inquiries through Email, Facebook, Linkedin, Twitter, etc

A wide selection of journals (inclusive of 9 subjects, more than 200 journals)

Providing a 24-hour high-quality service

User-friendly online submission system

Fair and swift peer-review system

Efficient typesetting and proofreading procedure

Display of the result of downloads and visits, as well as the number of cited articles

Maximum dissemination of your research work

Submit your manuscript at: http://papersubmission.scirp.org/ 